\title{
INTRODUCTION
}

\begin{tabular}{llll} 
Modernisation and Modernisation II & 0.08 & $\begin{array}{l}\text { The Commission's private enforcement } \\
\text { initiative }\end{array}$ & 0.15 \\
$\begin{array}{l}\text { The judicial route: the judgment of the Court } \\
\text { of Justice in Crehan }\end{array}$ & 0.14 & Methodology & 0.26 \\
\hline
\end{tabular}

This book sets out the current state of the law, both at European Union (EU) 0.01 and Member State level, in relation to actions for damages for loss caused by infringements of Articles 101 and 102 of the Treaty on the Functioning of the European Union (TFEU).

The antitrust rules contained in the TFEU are enforced both by way of decisions taken by competition authorities and other public authorities, ${ }^{1}$ and litigation brought before the courts by private parties in relation to an alleged infringement of the competition rules by another private party. ${ }^{2}$ While by 'public enforcement' is intended the application of those rules by public authorities, so-called 'private enforcement' thus consists in their application by courts in disputes between private parties. Despite the restricted subjectmatter of this book, it should be recalled that private enforcement of antitrust rules can take different forms, notably nullity of contracts if they infringe Article 101 TFEU (see Article 101(2) TFEU) or Article 102 TFEU, injunctive relief and damages actions.

What is meant by 'private enforcement' is enforcement by means of legal action 0.03 brought by the victim of anti-competitive behaviour before a court. This action

1 In certain Member States, as is the case in the US, decisions are taken by a court on the introduction of an action by the competition authority. This can be either a decision on infringement and sanctions, or a decision on sanctions only. The former applies in Austria, Estonia, Ireland and Sweden. The latter applies in Finland, where the case is brought before the Administrative Court, and Denmark (see further the Commission's Staff Working Document entitled 'Enhancing competition enforcement by the Member States' competition authorities: institutional and procedural issues', 9 July 2014 (SWD(2014)231), at para 11). The use of the term 'competition authority' includes reference to courts acting in such a capacity.

2 In the literature and policy documents, these modes of action are often referred to, respectively, as 'public' and 'private' enforcement of competition law. In respect of the latter, this may be a misnomer, as the purpose of the action from the point of view of the claimant is not law enforcement, but the specific remedy sought pursuant to a right, whether that be monetary (damages), or, for example, behavioural, such as an action for injunctive relief. The notion of 'private enforcement' probably derives ultimately from the vocabulary adopted by the Commission in its policy documents, since from the perspective of this institution, competition-related litigation has the primary function of supplementing or, in the wake of the modernisation reform, replacing the Commission's enforcement activity, and so is seen as a form of law 'enforcement'. 
is brought against the perpetrator of the behaviour and the victim will often seek a monetary award, known as damages, to compensate him for the harm he has suffered. Thus the infringer is held directly liable to the victim before a court of law. The courts charged with the responsibility of administering these actions in Europe are the national courts of the Member States. There is no court at $\mathrm{EC}$ level competent to hear actions between private parties for breach of EC competition law.

0.04 Private enforcement contrasts with public enforcement, whereby the public authorities (the Commission at EU level or the various national authorities in the Member States) investigate suspected violations of competition law and impose, where appropriate, fines to sanction infringement. Fines are paid into the public purse and the activities of the public enforcer are paid for by the state. Private enforcement actions are paid for by the individual bringing the action, and that individual can also recoup the money paid out as part of the award of compensation where the action is successful.

0.05 The principle of private enforcement of EU law rights, in addition to the enforcement activities of public authorities, goes back to the Van Gend judgment. In that case, the Court held that the fact that the Treaty contained provision for the enforcement by the Commission of obligations imposed by the Treaty did not preclude private enforcement of those obligations in proceedings before a national court. The Court expressed the principle of the complementary nature of public and private enforcement of rights deriving from EU law as follows:

The vigilance of individuals concerned to protect their rights amounts to an effective supervision in addition to the supervision entrusted by Articles [226] and [227] to the diligence of the Commission and of the Member States.

0.06 It should be noted at the outset that the situation in the EU stands in marked contrast to that in the US, where the contours and parameters of private antitrust enforcement are deeply ingrained in the legal system. As such, the development of the intricate legal rules concerning private damages actions, such as indirect purchaser standing and passing-on, is significantly different in the US from that in the EU. This can to a large extent be explained by the fact that the vast majority (approximately 90 per cent) of antitrust proceedings in the US are initiated by private parties, ${ }^{3}$ while in the EU, by contrast, antitrust

3 See, for example, DTI, 'A World Class Competition Regime' (July 2001), at Chapter 8, para 1. The fact that litigation outweighs public enforcement in the US has, however, attracted criticism from some commentators: '[t]he privatization of antitrust enforcement has many negative consequences. Private litigants often have interests that conflict with those of the intended beneficiaries of antitrust law-i.e. consumers - and can misuse antitrust to 
enforcement remains the quasi-exclusive preserve of the public enforcement authorities. As such, the weight accorded to the objectives to be attained by a system of private damages actions can be, and likely are, different between the two systems.

This said, there has been an increased interest in the private enforcement of EU competition law in recent years. This process received a significant boost from the modernisation of the enforcement of EU competition law carried out around the turn of the millennium, as well as judicial developments at around the same time.

\section{Modernisation and Modernisation II}

The decentralisation of the enforcement of Community antitrust law set in place by Regulation (EC) No 1/2003, ${ }^{4}$ which came into force on 1 May 2004, envisaged enforcement not only by the competition authorities of the Member States, but also a complementary role for private enforcement through litigation by private parties.

When drafting its proposal for the regulation, the Commission was aware that its monopoly on Article 101(3) represented a major obstacle to more extensive application of the competition rules by national courts. ${ }^{5}$ Article 101(1) prohibits agreements between undertakings which restrict competition. Agreements which have more positive than negative effects can be exempted from this prohibition. Article 101(3) sets out the conditions which agreements have to fulfil before they can be exempted. Under the former procedural rules, ${ }^{6}$ the Commission had sole power to apply Article 101(3). Regulation (EC) No $1 / 2003$ eliminated the exemption monopoly of the Commission, replacing it with a so-called 'legal exception' system whereby behaviour is legal or otherwise from its inception as a result of its characteristics, and not because the

facilitate rather than thwart anticompetitive behavior. Further, judges tend to limit their decisions in private litigation to the facts specific to each case. Thus, the fact that most antitrust liability rules are created in private litigation where courts err on the side of deliberate under-inclusion tends to dilute the strength of antitrust norms in public litigation' (Crane, D A, 'Antitrust Antifederalism' (2008) 96(1) California Law Review 1, at 38). For a recent reference to the 90 per cent figure, see Jones, A., 'Private Enforcement of EU Competition Law: a Comparison with, and Lessons from, the US', in Bergström, M, Iacovides, M and Strand, M (eds), Harmonising EU Competition Litigation: the New Directive and Beyond, Swedish Studies in European Law, Vol 8 (Oxford, Hart, 2016), at p 16.

4 Council Regulation (EC) No 1/2003 of 16 December 2002 on the implementation of the rules on competition laid down in Articles 81 and 82 of the Treaty (OJ L 1, 4.1.2003, p 1).

5 White Paper on modernisation of the rules implementing Articles 85 and 86 of the EC Treaty (COM(1999)101), para 100.

6 Council Regulation 17/62/EEC (first regulation implementing Articles 85 and 86 of the Treaty) (OJ L 13, 21.2.1962, p 204). 
Commission by administrative act has declared it to be legal. As a result, national judges are able to rule on Articles 101 and 102 in their entirety.

0.10 Article 6 of the Regulation states that national courts 'shall have the power to apply Articles [101] and [102]'..$^{7}$ Article 3 of the Regulation provides that national courts shall apply EU competition law to anticompetitive behaviour which may affect trade between Member States where they apply national competition law to such behaviour. In order to facilitate the application of EU competition law by the national courts, Article 15(1) of the Regulation expressly provides for a number of mechanisms by which courts can ask for opinions or information from the Commission.

0.11 Recital 7 to the Regulation explicitly acknowledges the important complementary role played by private damages actions before national courts to the public enforcement of EU competition law. It provides as follows:

National courts have an essential part to play in applying the Community competition rules. When deciding disputes between private individuals, they protect the subjective rights under Community law, for example by awarding damages to the victims of infringements. The role of the national courts here complements that of the competition authorities of the Member States.

0.12 Furthermore, the Commission Notice on complaints highlights that Regulation (EC) No 1/2003 'pursues as one principal objective that Member States' courts and competition authorities should participate effectively in the enforcement of Articles 81 and 82'. ${ }^{8}$ The Notice further states that 'the new enforcement system established by Regulation 1/2003 strengthens the possibilities for complainants to seek and obtain effective relief before the national courts'. ${ }^{9}$ The Notice indicates the importance of private actions to the enforcement of EU competition law.

0.13 Modernisation of EU competition law opened the way for increased private enforcement of the competition rules by removing the Commission's monopoly over Article 101(3) exemptions, and by empowering national courts to apply those rules. Private enforcement of competition law was central to the vision behind the first round of modernisation.

7 The Commission had gone further in its White Paper, stating that national courts were the most appropriate forum for the enforcement of EU competition law. This is because they are in a position, in contrast to the Commission, to award damages (see para 46: 'The national courts for their part are in a better position than the Commission to accede to certain requests by complainants: they can act rapidly through interlocutory proceedings and, unlike the Commission, can grant damages to those who have been the victims of infringements.').

8 Commission Notice on the handling of complaints by the Commission under Articles 81 and 82 of the EC Treaty (OJ C 101, 27.4.2004, p 65), at para 9 (see generally part II.A and B).

9 Ibid., para 18. 
The judicial route: the judgment of the Court of Justice in Crehan

At around the same time as the modernisation initiative, in its Crehan

judgment of 2001, ${ }^{10}$ the Court of Justice ruled that the full effectiveness of Articles 101 and 102 TFEU demands that anyone who has suffered a loss because of an infringement of the rules laid down in these articles be able to recover those losses from the infringer.

\section{The Commission's private enforcement initiative}

In order to advance its policy aim of facilitating the bringing of antitrust 0.15 damages claims, the Commission started looking at the issue in 2003 with the launching of the Ashurst study, ${ }^{11}$ which led to the adoption of a Green Paper in 2005. ${ }^{12}$ This was followed by a White Paper in 2008, ${ }^{13}$ and shortly afterwards the Commission attempted to adopt a legislative proposal in the field as almost the final act of the tenure of Commissioner Kroes at DG Competition. ${ }^{14}$

After the withdrawal of the so-called 'draft Directive', DG Competition

became embroiled in the Commission's initiative on collective redress, which stretched over several years during the term of the Barroso II Commission. However, a long-awaited second shot at a legislative initiative, without a provision on collective redress, was adopted in June $2013,{ }^{15}$ together with a recommendation and a communication on collective redress. ${ }^{16}$

10 Judgment of 20 September 2001 in Case C-453/99 Courage Ltd v Bernard Crehan (EU:C:2001:465).

11 Ashurst, Study on the Conditions of Claims for Damages in Case of Infringement of EC Competition Rules, 31 August 2004 (the 'Ashurst study'), available at: http://ec.europa.eu/competition/antitrust/actionsdamages/ study.html. The Ashurst study is comprised of a comparative report and 25 national reports, as well as an analysis of methods of quantifying harm.

12 Green Paper on damages actions for breach of the EC antitrust rules (COM(2005)672), and accompanying Staff Working Paper (SEC(2005)1732), of 19 December 2005 (the 'Green Paper').

13 White Paper on damages actions for breach of the EC antitrust rules (COM(2008)165), and accompanying Staff Working Paper (SEC(2008)404), of 2 April 2008 (the 'White Paper').

14 Proposal for a Council directive on rules governing damages actions for infringements of Articles 81 and 82 of the Treaty, 2009, referred to throughout as the 'draft Directive'.

15 Proposal for a directive of the European Parliament and of the Council on certain rules governing actions for damages under national law for infringements of the competition law provisions of the Member States and of the European Union (COM(2013)404) ('the proposal'). At the same time, the Commission adopted a communication on quantifying harm in actions for damages based on breaches of Article 101 or 102 of the Treaty on the Functioning of the European Union (C(2013)3440), as well as an accompanying Staff Working Document ('Practical Guide') on quantifying harm (SWD(2013)205).

16 Commission Recommendation 2013/396/EU of 11 June 2013 on common principles for injunctive and compensatory collective redress mechanisms in the Member States concerning violations of rights granted under Union law (OJ L 201, 26.7.2013, p 60), and Communication entitled 'Towards a European horizontal framework for collective redress' (COM(2013)401). These are referred to throughout as 'the 2013 recommendation' and 'the 2013 communication' respectively. 
0.17 Following the adoption of the Commission's proposal, the legislative procedure was concluded relatively swiftly by the co-legislators, allowing for agreement of a political compromise before the end of the legislature in 2014. The politically-agreed text was adopted by the European Parliament on 17 April $2014,{ }^{17}$ while the final version of the Directive was adopted by the Council on 10 November 2014. The act was signed on 26 November 2014, and published in the Official Journal on 5 December 2014.18 It entered into force on 25 December $2014,{ }^{19}$ and the deadline for transposition by the Member States was 26 December 2016.20

0.18 While, at first sight, it may be argued that the bringing of private damages actions has not proven to be the panacea that, from a policy perspective, it was hoped to be, such an assessment fails to take into account certain issues. The paucity of extensive and consistent European-wide empirical evidence on the matter belies the fact that there is a growing trend of private damages claims being brought before national courts. ${ }^{21}$

0.19 A significant proportion of damages claims is often settled before a final decision is reached. While settlement is to be encouraged in the sense that it is often in the best interests of the parties concerned, this arguably prematurely curtails the development of case-law.

0.20 Settlements between the parties operate in the shadow of the law and the frequency and ways in which parties reach settlements will be influenced by the legal framework in which the threat of litigation operates, and vice versa. However, information on settlements is by its nature difficult to come by, as settlements are typically confidential. Settlements are very rarely reported, as a party that agrees to pay damages out of court typically will include, as a condition of the settlement, that the matter must be kept confidential. It is

17 P7_TA(2014)0451. Within the Parliament, competence for the file was shared between the Economic and Monetary Affairs Committee (ECON) and the Legal Affairs Committee (JURI) (see the report of the ECON Committee and the opinion of the JURI Committee in file 2013/0185(COD)).

18 Directive 2014/104/EU of 26 November 2014 on certain rules governing actions for damages under national law for infringements of the competition law provisions of the Member States and of the European Union (OJ L 349, 5.12.2014, p 1). References to 'the Directive' throughout are to this act.

19 Article 23.

20 Article 21(1).

21 There have been some useful empirical studies on particular countries. In relation to the United Kingdom, see Rodger, B, 'Competition Law Litigation in the UK Courts: A Study of All Cases to 2004' - Parts I-III [2006] ECLR 241-48; 279-92 and 341-50; Rodger, B, 'Competition Law Litigation in the UK Courts: A Study of all Cases 2005-2008' - Parts I and II [2009] GCLR 93-114 and 136-47. In relation to Germany (albeit limited to two years), see Peyer, S, 'Private Antitrust Litigation in Germany from 2005 to 2007: Empirical Evidence' (2012) 8(2) Journal of Competition Law and Economics 331-59. 
very difficult, therefore, to establish exactly how many settlements are reached in relation to competition damages actions. ${ }^{22}$

In addition, important yet difficult matters of a procedural nature have 0.21 occupied the courts with respect to damages actions. As the number of actions brought before national courts has increased, the courts have been faced with novel procedural points of law that have to be addressed. At times, these issues are often litigated all the way to courts of last instance, further prolonging the commencement of any substantive assessment of a damages claim.

As the procedural landscape of private actions becomes clearer, claims are being brought in increasing numbers, despite such cases being complex and difficult to run. In other words, once the docket of procedural cases is cleared, further claims can be brought with a better view as to the procedural requirements.

Ultimately, it remains evident that, notwithstanding the slow start, private enforcement of competition law in the EU is a topic of the utmost importance to practitioners and in-house counsel, as well as to their clients, as lawyers increasingly have to advise on the complex, and potentially costly, matter of antitrust damages exposure.

The foregoing is true not only for lawyers within the EU, but also for lawyers and undertakings based outside the EU, since such companies, if they trade within the EU, are subject to EU competition law, and therefore can be subject to damages claims before the courts of a Member State.

Although the design of the private enforcement system in the US is different, in particular in that damages are multiplied in order to maximise the deterrent effect of the system, on the basis of the experience in that jurisdiction, it can be asserted that damages actions have a significant potential to act as a financial incentive for companies to comply with the law. ${ }^{23}$

22 For an in-depth study, see, for example, Rodger, B, 'Private Enforcement of Competition Law, The Hidden Story: Competition Litigation Settlements in the UK 2000-2005' [2008] ECLR 96.

23 In this regard, see, for example, Cartel Damage Claims, 'Implementation of Directive 2014/104/EU on certain rules governing actions for damages under national law for infringements of the competition law provisions of the Member States and of the European Union into national law' ('CDC implementation paper'), at $\mathrm{p}$ 1: 'CDC has successfully concluded several complex out-of-court settlements, many of them totalling tens of millions of Euros' (https://www.carteldamageclaims.com/wp-content/uploads/2017/04/Directive_ implementation_national-governments1.pdf). 


\section{Methodology}

0.26 As just explained, the two-tier framework for the bringing of damages actions in the EU has given rise to the adoption of several Commission documents on the subject, and the reader is referred to these and other publications ${ }^{24}$ for the surrounding policy debate. In the chapters that follow, I will discuss and analyse the relevant policy proposals, but the purpose is not to make policy recommendations.

0.27 In terms of methodology, the approach adopted has been to start from EU law, meaning both positive law available in relation to the issues considered as well as any law that can be referred to by analogy, and also policy developments in the field. I then go on to consider the relevant law of the Member States, either used as a means of comparison to EU law, or, as often, in the absence of such law. Finally, I also examine the US system, which is arguably the most mature regime in this field, as a source of comparison to existing, or missing, EU law.

0.28 As regards national law, I have not exhaustively examined the law of all 28 Member States in relation to each issue. Instead, I have selected, in the first place, those jurisdictions which have shown themselves to be the more significant fora for the bringing of competition damages actions. This has been supplemented by analysis of other legal systems which show themselves to be of particular interest. In addition, this form of selection of national law has also, as necessary, been supplemented by a comparative approach, whereby I have selected representative jurisdictions from the major European legal families.

0.29 In the chapters that follow, I analyse certain key issues on a selective basis. This provides the basic structure of the book. These issues are, briefly stated, indirect purchaser standing and passing-on; evidential issues, including the question of access to the file for the purpose of substantiating a damages claim; collective redress; and the relevant private international law, namely choice of court and the law applicable to the claim. The book concludes with a chapter on the quantification of damages, authored by specialist economists.

0.30 This book is not intended as an exhaustive reference work containing details of all competition-related litigation brought in the Member States. My intention

24 As well as the Ashurst study, see, for example, CEPS/EUR/LUISS, Making antitrust damages actions more effective in the EU: welfare impact and potential scenarios, 21 December 2007, which formed the background to the Commission's Impact Assessment of 2 April 2008 (SEC(2008)405), adopted at the same time as the White Paper (the 'White Paper Impact Assessment'). 
has rather been to introduce the issues, explaining them to an audience which is not necessarily expert, and placing the whole field of competition law litigation in a theoretical, practical and comparative context. 